\title{
Pengaruh Pemberian Kurma Muda (Phoenix dactylifera) Terhadap Kadar FSH dan Reseptor FSH Ovarium Tikus Putih (Rattus norvegicus)
}

\author{
Herlambang1, Ave Olivia Rahman², Erny Kusdiyah ${ }^{3}$ \\ ${ }^{1}$ Departemen Obstetri dan Genikologi Fetomartenal, Fakultas Kedokteran dan IImu Kesehatan \\ Universitas Jambi/ Rumah Sakit Umum Daerah Raden Mattaher \\ ${ }^{2}$ Departemen Farmakologi, Fakultas Kedokteran dan IImu Kesehatan Universitas Jambi \\ ${ }^{3}$ Departemen Kesehatan Masyarakat, Fakultas Kedokteran dan IImu Kesehatan Universitas Jambi \\ herlambang07@yahoo.co.id
}

\begin{abstract}
Background: Infertility may give an impact on psychosocial. In Indonesia, the habit of consuming young dates is often done by couples to increase fertility. FSH is one of the factors that play a role in folliculogenesis. The lack of scientific evidence of young dates consumption effects on female reproduction has led to this study. This study aims to determine the levels of FSH hormone and the picture of ovarian tissue in mice after administration of young dates.

Method: This study used an experimental design using 28 female Sprague-Dawley rats which were randomly divided into 4 groups. Group I to III was given young dates in successive doses: $17 \mathrm{mg}, 34 \mathrm{mg}$, $68 \mathrm{mg}$ per 200 grams of body weight and group IV was given distilled water. The treatment was carried out for 28 days. FSH levels were examined before treatment during the proestrus phase which was known from microscopic examination of rat vaginal swabs. The treatment begins during the proestrus phase.

Result: The mean baseline and post-treatment FSH levels were 0.08 and 0.09 respectively

Conclusion: There is no significant increase of FSH levels and FSH receptors as the effect of giving young dates (Phoenix Dactylifera) to female Sprague-Dawley rats
\end{abstract}

Keywords: Dates, FSH, FSH receptors, Rats

\section{ABSTRAK}

Latar Belakang: Infertilitas dapat memberikan dampak psikososial. Di Indonesia, kebiasaan mengkonsumsi kurma muda sering dilakukan oleh pasangan untuk meningkatkan kesuburan. Hormon FSH merupakan salah satu faktor yang berperan dalam folikelgenesis. Belum adanya bukti ilmiah efek konsumsi buah kurma muda terhadap reproduksi wanita mendorong dilakukannya studi ini. Studi ini bertujuan mengetahui kadar hormon $\mathrm{FSH}$ dan gambaran jaringan ovarium pada tikus setelah pemberian kurma muda.

Metode: Penelitian ini menggunakan desain ekperimental menggunakan tikus Sprague dawney betina sebanyak 28 ekor yang dibagi secara acak menjadi 4 kelompok. Kelompok I-III diberikan kurma muda dosis berturut -turut 17 mg, 34 mg, 68 mg per 200 gram BB dan kelompok IV diberikan aquadest. Perlakuan dilakukan selama 28 hari. Kadar hormon FSH diperiksa sebelum perlakuan saat fase proestrus yang diketahui dari pemeriksaan mikroskopis swab vagina tikus. Perlakuan dimulai saat fase proestrus. Hasil: Rerata kadar FSH baseline dan paska perlakuan adalah 0,08 dan 0,09 
Kesimpulan: Tidak terdapat peningkatan yang signifikan kadar $\mathrm{FSH}$ dan reseptor FSH terhadap efek pemberian buah kurma muda (Phoenix Dactylifera) pada uterus tikus Spague Dawney

Kata kunci : kurma, FSH, Reseptor FSH, tikus

\section{PENDAHULUAN}

Infertilitas dapat menimbulkan dampak psikososial bagi keluarga. Infertilitas yang didefinisikan sebagai kegagalan untuk hamil setelah satu tahun mencoba kehamilan dengan melakukan hubungan seksual secara teratur tanpa kontrasepsi, dianggap sebagai masalah di hampir semua budaya dan masyarakat. The World Health Organization (WHO) memperkirakan sekitar 8-10\% pasangan usia subur mengalami masalah kesuburan. Di Indonesia, pada tahun 2007, dari sekitar 30 juta pasangan usia subur terdapat 3-4,5 juta atau sekitar 10$15 \%$ pasangan yang memiliki problem kesuburan. ${ }^{1-3}$

Pada kasus infertilitas, perempuan memiliki peran sebesar $40 \%-50 \%$ kasus sedangkan laki-laki sebesar $30 \%$ dan penyebab lain sekitar 20\%-30\% dari pasangan. Infertilitas sebagian besar disebabkan oleh perempuan, oleh karena itu dampak dari infertilitas memiliki pengaruh lebih besar bagi perempuan. Infertilitas yang disebabkan oleh faktor perempuan antara lain anovulasi, kerusakan tuba, endometriosis dan kegagalan ovarium. 2,3,4-6

Pencarian obat herbal sebagai penambah fertilitas meningkat signifikan. $\mathrm{Di}$ seluruh dunia banyak tanaman tradisonal yang digunakan sebagai peningkat kesuburan. Salah satu obat herbal yang digunakan untuk penambah fertilitas adalah buah kurma muda. Studi mengenai serbuk bunga kurma dosis 400 $\mathrm{mg} / \mathrm{kgBB}$ dapat menyebabkan peningkatan hormon seks (FSH/ Follicle Stimulating Hormone, LH/Luteinezing Hormone dan GSH/Gonadothropine Stimulating Hormone) dan menstimulasi folikelgenesis yaitu peningkatan jumlah folikel ovarium sekunder dan antral pada tikus BALB/c betina. ${ }^{7-9}$

FSH adalah hormon yang dikeluarkan hipofise yang berperan untuk memacu pertumbuhan dan kematangan folikel atau sel telur dalam ovarium dan juga berpengaruh pada peningkatan hormon estrogen pada wanita. ${ }^{5-7}$

Mayoritas masyarakat Indonesia mengkonsumsi buah kurma muda yang dipercaya sebagai penambah fertilitas, akan tetapi belum ada data ilmiah mengenai efektivitas dan mekanisme dari buah kurma muda sebagai penambah fertilitas pada wanita. Penelitian ini dilakukan untuk memberikan data ilmiah mengenai efektivitas buah kurma muda sebagai penambah fertilitas pada wanita melalui metode uji invivo pada tikus putih betina untuk melihat pengaruh buah kurma muda terhadap kadar FSH dan jaringan ovarium. ${ }^{10,11}$

\section{METODE}

Penelitian ini adalah penelitian eksperimental yang dilakukan pada Bulan Juli sampai September 2018 di 
$\begin{array}{lrr}\text { Laboratorium Biomedik } & \text { Fakultas } \\ \text { Kedokteran } & \text { dan }\end{array}$

Universitas Jambi dan telah mendapatkan persetujuan etik dari Komisi Etik Fakultas Kedokteran dan IImu Kesehatan Universitas Jambi.

\section{Bahan}

Buah kurma muda yang digunakan berasal dari buah berwarna hijau kekuningan yang diperoleh di Toko Kurma dan telah dilakukan determinasi spesies buah. Daging buah kurma dikeringkan di dalam oven dengan suhu $70 \square \mathrm{C}$ selama 24 jam kemudian dihaluskan menggunakan blender.

Hewan percobaan yang digunakan adalah tikus betina galur Sprague Dawley berusia sekitar 2-3 bulan, memiliki berat 150-200 gram, diketahui riwayat kehamilan sebelumnya yang diperoleh dari Fakultas Kedokteran dan IImu Kesehatan Universitas Jambi. Jumlah sampel adalah 6 ekor tikus betina setiap kelompok.

\section{Prosedur Kerja}

\section{Penentuan fase proestrus}

Tikus dilakukan swab vagina dengan metode pemeriksaan yang dijelaskan pada penelitian sebelumnya. Pemeriksaan dilakukan selama 4 hari berturut-turut untuk mengetahui hari saat tikus berada dalam fase proestrus.

\section{Perlakuan}

Tikus dibagi secara random menjadi 5 kelompok yaitu Kelompok I diberikan kurma dosis $17 \mathrm{mg} / 200 \mathrm{gramBB}$, kelompok II diberikan kurma dosis 34 mg/200 gramBB , Kelompok III diberikan kurma dosis $68 \mathrm{mg} / 200$ gramBB dan kelompok IV diberikan aquadest.

Kurma ditimbang sesuai dosis pemberian dan ditambahkan aquadest sebanyak $2 \mathrm{ml}$. Larutan tersebutk diberikan ke tikus menggunakan sonde. Perlakuan diberikan satu kali setiap hari selama 28 hari.

\section{Pemeriksaan kadar serum FSH}

Pengambilan darah dilakukan di sinus retrobulbar sebanyak 1, $5 \mathrm{ml}$. Pengambilan darah dilakukan sebanyak 2 kali, sebelum perlakuan saat tikus dalam fase proestrus dan sebelum terminasi. Pemeriksaan beta FSH menggunakan metode ELVA.

\section{Analisis data}

Data dalam penelitian ini dianalisis dengan metode statistik Kruskal Wallis yang dilanjutkan dengan uji Mann Whitney $U$ untuk mengetahui beda rerata lebih dari 2 kelompok. Hasil uji statistik dinyatakan signifikan jika nilai $p<0,05$.

\section{HASIL DAN PEMBAHASAN}

Sebelum dilakukan pengambilan darah untuk pemeriksaan kadar hormone sebelum perlakuan (pretest/baseline) perlu dilakukan penentuan siklus estrus tikus. Pengambilan darah dilakukan saat tikus dalam fase proestrus yaitu fase dimana kadar FSH tertinggi selama siklus estrus. Penentuan fase estrus dilakukan dengan swab vagina yang dilakukan selama 4 hari berturut-turut untuk setiap tikus. Gambaran siklus estrus dapat dilihat pada gambar dibawah ini. ${ }^{11-14}$ 


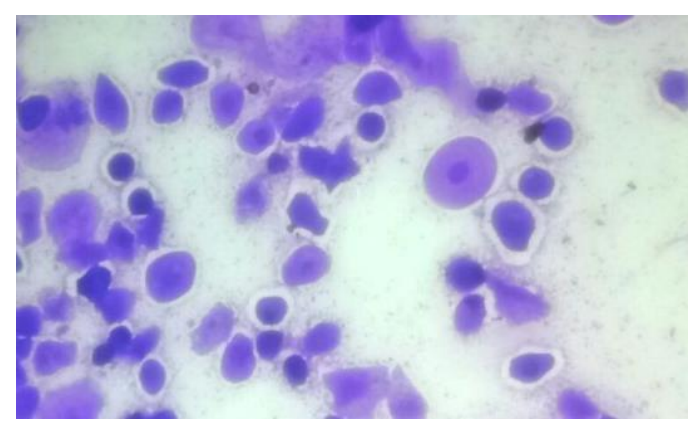

Gambar 1. Fase proestrus

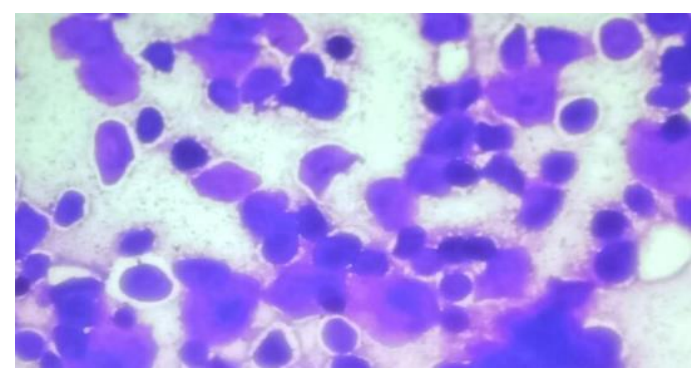

Gambar 2. Fase estrus

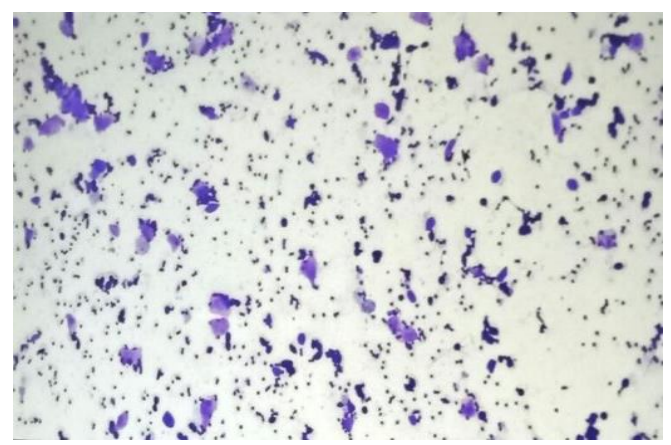

Gambar 3. Fase Metetrus

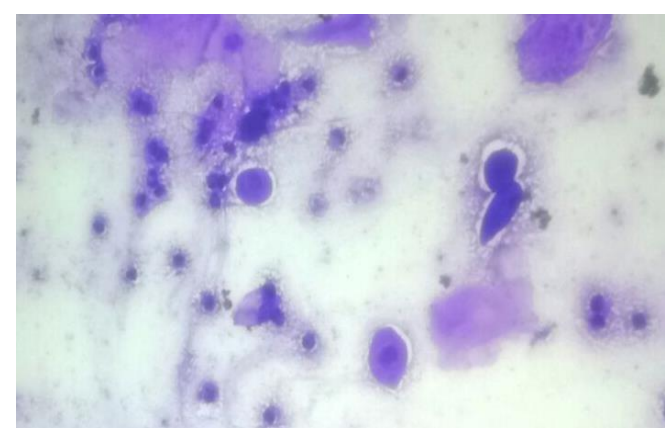

Gambar 4. Fase Diestrus
Hasil pemeriksaan kadar FSH sebelum perlakuan pada semua kelompok menunjukkan rata- rata kadar FSH 0,08. Selanjutnya , setiap tikus diberikan perlakuan sesuai kelompok masing- masing menggunakan sonde selama 28 hari dimulai dari fase proestrus. Pada hari ke 29 dilakukan pemeriksaan kadar FSH setelah perlakuan pada semua kelompok menunjukkan rata-rata kadar FSH 0,09, kemudian akan dilakukan terminasi pada fase proestrus untuk pengambilan organ ovarium kanan dan kiri untuk dilakukan pemeriksaan histopatologi ovarium menggunakan pewarnaan Haematoxilin Eosin 15,16. Pembacaan dilakukan oleh ahli Patologi anatomi secara blind meliputi folikel primordial, tunika albuginea, epitel germinativum dan stroma. ${ }^{17-20}$

\section{KESIMPULAN}

Pada penelitian ini tidak terdapat peningkatan yang signifikan kadar FSH dan reseptor FSH terhadap efek pemberian buah kurma muda (Phoenix Dactylifera) pada uterus tikus Spague Dawney . 


\section{DAFTAR PUSTAKA}

1. Abdul Basith Muhammad Sayyid, Ketika Rasulullah Tidak Pernah Sakit Gaya Hidup Sehat Islami, Creative Imprint of Tiga Serangkai, Tinta Madina, Solo, 2012.

2. Cao ZT, Swift TA, West CA, Rossano TG dan Rej R. 2004. Immunoassay of estradiol: unanticipated suppression by unconjugated estriol. Clin Chem 50(1):160-165.

3. Fouad Mehraban, Mehrzad Jafari, Mehdi Akbartabar Toori, Hossein Sadeghi, Behzad Joodi., et all. 2014. Effects of date palm pollen (Phoenix dactylifera L.) and Astragalus ovinus on sperm parameters and sex hormones in adult male rats. Iran J Reprod Med Vol. 12. No. 10. pp: 705-712.

4. Amori G dan Clout M. 2002. Rodent on Island: A Conservation Challenge. In: Singelton GR, $L A$ Hinds, C H Krebs, D M Spratt (Ed). Rats, Mice and people: Rodent Biology and Management. Canberra: Australian Centre for International Agriculture Research.

5. Guyton AC dan Hall JE. 1997. Buku Ajar Fisiologi Kedokteran. Ed ke-9. Setiawan, Tengadi, dan Santoso, penerjemah; Setiawan, editor. Jakarta: EGC. Terjemahan dari: Textbook of Medical Physiology.

6. Hafez ESE, Jainudeen MR, dan Rosnina Y. 2000. Hormones Growth Factors and Reproduction. Di dalam : Reproduction in Farm Animals. Ed ke-3. Philadelphia: Lippincott Williams and Wilkins.

7. Hosseini SE, Mehrabani D, Razavi F. Effect of palm pollen aqueous extract on the sex ratio of offspring in mice strain BALB/c. Q Res J Lorestan Uni Med Sci. 2013;15:121-128.

8. Cao ZT, Swift TA, West CA, Rossano TG dan Rej R. 2004. Immunoassay of estradiol: unanticipated suppression by unconjugated estriol. Clin Chem 50(1):160-165.

9. Cassidy A, Paola A, Inge LN, Wendy H, Gary W, Inge T, Steve A, Heide C, Yannis M, Alicja W, Claudia S, dan Francesco B. 2006. Critical review of health effects of soyabean phyto-oestrogens in post-menopausal women. Proceedings of the Nutrition Society 65:76-92.

10. Hassan WA, El-kashlan AM, Ehssan NA. Egyptian date palm pollen ameliorates testicular dysfunction induced by cadmium chloride in adult male rats. J Am Sci. 2012;8:659-669.

11. Khan I, Belanger A, Chen YDI, Gibori G. 1985. Influence of HDL on estradiol stimulation of luteal steroidogenesis. Biol Reprod. 32:92-104.

12. Cooke PL, Buchanan DL, Lubchan DB dan Cunha GR. 1995. Mechanism of estrogen action: lessons from the estrogen receptor- $\alpha$ knockout mouse. Biol Reprod 59:470-475.

13. El-Neweshy MS, El-Maddawy ZK, El-Sayed YS. Therapeutic effects of date palm (Phoenix dactylifera L.) pollen extract on cadmium-induced testicular toxicity. Andrologia. 2012;45: 369-378.

14. Hedrich HJ. 2006. Taxonomy and stock and strains. J Lab Rat 71-92. Hill M. 2006. Estrous Cycle. The University of New Southwales. Sidney.

15. Jha RK dan Zi-roung X. 2004. Biomedical compounds from marine organisms (review). Marine Drugs 2:123-146.

16. Marbeen MI, Al-Snafi AE, Marbut MM, Allahwerdy IY. The probable therapeutic effects of date palm pollen in the treatment of male infertility. Tikrit J Pharm Sci. 2005;1:30-35.

17. Moshtagh A, Johari $\mathrm{H}$, Shariati M, Amiri J, Effect of Pheonix Dactylifera on serum concentration of Estrogen, progestron and gonadotropins in adult female rat, Jafsanjan Uni Med Sci J, 9(2), 2010, 117-124.

18. Hassan HMM, Chemical composition and nutritional value ofpalm pollen grains. Global $\mathrm{J}$ Biotech Biochem. 2011;6:1-7.

19. Haug T, Kjuul AK, Styrvold OB, Sandsdalen E, Olsen OM, Stensvag K. 2002. Antibacterial Activity in Strongylocentrotus droebachiensis (Echinoidea), Cucumaria frondosa (Holothuroidea), and Asterias rubens (Asteroidea). Journal of Invertebrate Pathology 81:94- 102.

20. Kazeminia SM, Ebrahimi Vosta Kalaee S, Nasri S. Effect of dietary intake alcoholic extract of palm pollen (Phoenix dactylifera L.) on pituitary-testicular axis in male diabetic rats. J Mazand Univ Med Sci. 2014;24:167S-175S. 